Article

\title{
Development of Food Competence in Early Childhood Education
}

\author{
Luisa López-Banet ${ }^{1, *(D)}$, José Antonio Miguélez Rosique ${ }^{2}$, Marina Martínez-Carmona ${ }^{1}$ (D) \\ and Gabriel Enrique Ayuso Fernández ${ }^{1}$
}

1 Department of Science Education, University of Murcia, 30100 Murcia, Spain; marina.m.c1@um.es (M.M.-C.); ayuso@um.es (G.E.A.F.)

2 CEIP_Public School Santa María de Gracia, 30009 Murcia, Spain; joseantonio.miguelez@murciaeduca.es

* Correspondence: llopezbanet@um.es

check for

updates

Citation: López-Banet, L.;

Miguélez Rosique, J.A.;

Martínez-Carmona, M.;

Ayuso Fernández, G.E. Development

of Food Competence in Early

Childhood Education. Educ. Sci. 2022,

12, 64. https://doi.org/

10.3390/educsci12020064

Academic Editors:

Konstantinos Ravanis

and Kendall Hartley

Received: 8 October 2021

Accepted: 15 January 2022

Published: 19 January 2022

Publisher's Note: MDPI stays neutral with regard to jurisdictional claims in published maps and institutional affiliations.

Copyright: (C) 2022 by the authors. Licensee MDPI, Basel, Switzerland. This article is an open access article distributed under the terms and conditions of the Creative Commons Attribution (CC BY) license (https:// creativecommons.org/licenses/by/ $4.0 /)$.

\begin{abstract}
The increase in childhood obesity requires the incorporation of nutritional competence into school programs through appropriate activities, starting in the early years. In addition, it is important to promote scientific and cognitive skills during childhood education. The main objective of this study was the implementation of an instructional sequence focused on the learning of skills such as observation, measurement, or interpretation of data related to plants, their germination, and their growth, as well as its relation with the development of food competence. To do so, a set of differentiated activities, organized into several stages, was designed, starting from simple and concrete situations and progressively increasing in complexity and abstraction. The aims were to express ideas about known fruits, vegetables, and legumes in order to expand them by learning new information through student-centered activities, in which children were able to practice and talk about science. The activities were carried out in a class of 24 students aged $4-5$ years and data were compared with a control group. The results revealed that the children were motivated in all the activities, which provided an excellent opportunity to initially develop an interest in science and to start to develop food competence in the early years.
\end{abstract}

Keywords: early childhood science education; scientific competence; teaching interventions and activities teacher training; inquiry; scientific practice; health; school gardens; sustainability education; cognitive skills; experimental skills

\section{Introduction}

During the last 30 years, educational research has tried to justify the importance of developing scientific competence during early childhood education and not to wait for higher courses in which students have greater cognitive abilities, as well as to deepen the training that teachers should receive to promote their development. In this regard, numerous contributions have been made in the field of science education to characterize what it would mean for students to learn to 'do science' in classrooms, that is, to involve them in activities related to abilities; skills; and cognitive, manipulative, communicative, and research strategies of greater or lesser complexity, to transfer to the school level the work methods that characterize scientific activity [1-4]. For example, in Spain, Jiménez and Sanmartí [5] pointed out that in addition to the learning of concepts, compulsory education should promote the development of cognitive skills (scientific reasoning), experimental skills and problem solving, thus promoting the development of attitudes and values of scientific activity. In this way, the transmitted image of science would correspond to current concepts.

Based on these and other contributions and evidence from educational research, the OECD proposed the term scientific competence, which includes the capacity for inquiry linked to specific contexts and the integration of knowledge. This term refers, among other 
aspects, to the use that individuals make of scientific knowledge to identify problems, acquire new knowledge, explain scientific phenomena, and draw evidence-based conclusions on science-related issues [6]. Other authors, such as Chamizo and Izquierdo [7], understand scientific competence as the set of capacities that allow knowing, knowing how to do things, as well as being and living with others, in life situations in which one must decide how to act. Franco [8] relates it to 15 capacities grouped into seven dimensions, ranging from the identification of the problem or the formulation of research objectives and hypotheses to the analysis of data, the establishment of conclusions, and the communication of results.

\subsection{Teaching Science in Early Childhood Education}

To answer the question of why it is necessary to develop scientific competence during early childhood education, we will refer to points of view such as those of Harlen $[2,9,10]$ and Osborne and Dillon [11]. These authors justify the importance of science education from elementary educational levels for two main reasons: (1) the need to create scientifically literate citizens from childhood, so that they can successfully face the challenges of a society steeped in science and technology; (2) its propaedeutic purpose, since this literacy must continue to develop, at least, in the following educational stages of compulsory education. Furthermore, a higher relationship with prior learning experiences in order to explain and interpret other observed phenomena is expected to exist among children who are used to engaging in inquiry-based activities [12]. Therefore, postponing this training to higher levels would not promote adequate development of the aforementioned training dimensions, nor would it take advantage of the impact that teaching based on school research could have during early childhood and primary education on students' attitudes towards scientific subjects. This late introduction could have a negative impact on the choice of future scientific pathways $[3,13]$ and in the aspirations to carry out scientific careers in the future [14]. As Criado and Cruz-Guzmán [15] point out, interest and attitudes towards science are generated before the age of 14 , so steps must be taken in the basic stages to ensure quality science education [11]. Several works have addressed the characteristics of the different approaches to children's science education. Among these, it is worth highlighting the review by Ravanis [16] that classifies the proposals into four categories, where not only are the approaches diverse, but the teacher also plays different roles in each one: (1) empiricist approaches, with clear leadership from the teacher who proposes teaching topics directly extracted from the natural sciences; (2) Piagetian approaches, in which the teacher helps, encourages, and facilitates the students' work by recording their choices and obstacles; (3) sociocognitive, with the intention of the teacher to create the right conditions for the active participation of children, allowing them to rebuild their thinking towards a precursor model level; and, more recently, (4) the sociocultural approach, in which the teacher organizes and supports a communication framework and a school environment that allows the emergence and exploitation of elements of human activity in general.

In early childhood education, procedures have been proposed $[17,18]$ that are fundamental for an initial approach of schoolchildren to scientific perspectives in reality $[19,20]$. Health, the environment and communication are three areas of science important to the lives of citizens [21]. Within these, we will focus on aspects related to food and the environment in early childhood education, since this stage constitutes a key moment in which boys and girls acquire habits and develop behaviors for the future [22]. In this sense, many schoolchildren are reluctant to eat vegetable products and often do not reach the recommendation of five fruits and vegetables a day and exceed the recommended consumption of meat [23]. Therefore, it is necessary to know what the factors are that contribute to the acceptance of food and how this acceptance can contribute to liking a more varied diet in childhood [24].

\subsection{Development of Healthy Feeding Learning in the Early Years}

The knowledge regarding how young children think about food is very scarce [25], since the way in which children learn about healthy eating is extremely complex [26]. In 
addition, there is a lack of empirical research on the formation of scientific concepts between 0 and 3 years. This can be attributed to two factors: on the one hand, the limited verbal skills of students at this age makes it difficult to collect information, and on the other hand, this stage-historically understood as childhood-used to be exclusively focused on care. Only recently has it started to be considered in relation to formal education, and it has become possible to introduce research considering infant children capable of acting as 'scientists' [27]. Children learn about food as they develop perception, cognition, behavior, and experiences with it. Two effective techniques for learning about food, especially for younger children, are familiarization through repeated exposure to its taste, texture or appearance, and observational learning by choosing foods by mimicking others' eating behavior [28]. In familiarization learning, the evaluation of a stimulus increases after repeated exposure, which is reflected in the selection of those foods that have been repeatedly experienced in their environment. Thus, if children at early ages have frequent experiences with healthy foods, they will be more likely to promote the acceptance of these options in the future, even among many high-energy foods. Observational learning arises due to the opportunities for children to feel influenced by the eating behaviors of others when they eat in social contexts, so it can have positive or negative effects, depending on who their food models are. For example, the consumption of unhealthy food will promote the intake of these foods in children, with negative effects on the quality of the diet [29]. Data have shown that preschool-aged children's food preferences and consumption are strongly influenced by those of other children. Exposing the children to peers who were selecting and eating certain foods not preferred by them initially was enough for them to change their selection after observing their peers, even in the presence of an initially chosen food. This shows that peer models were effective in altering preferences, for example, for preschoolers' vegetable consumption at lunch [30]. Actively positive social role models, provided by adults and peers, can be effective in promoting healthier eating, so the introduction of a new food could be conducted initially in a moderated way through brief repeated tasting of the food in a positive social context [31]. Conversely, foods associated with negative social contexts may become less preferred or rejected [32]. Due to the coercion and interpersonal conflict that the forced consumption situation implies, the exact opposite occurs, and children will be less likely to consume the desired food in the future. Therefore, if the child does not want to eat the new food, it is best not to force him to do so and to try again at another time.

Other techniques for setting food preferences are associative learning through the introduction of flavors and food categorization. In the first one, an initially neutral (conditioned) stimulus begins to elicit responses after being repeatedly introduced together with a significant (unconditioned) stimulus. In the second, what a child will be willing to consume will depend on their ability to recognize the items on their plate as familiar specimens of that type of food, and therefore, the categorization of foods could have an influence on their taste for healthy foods [28].

With age, factors such as peers and the availability of food continue to shape the food preferences and behaviors of schoolchildren [33]. However, from preschool to the beginning of primary school, children's knowledge about food improves and significant differences can be seen between them [26]. There is a change in children's thinking about preferences, appropriate situations for eating fruits and vegetables, and wholesomeness. The importance they attach to the attributes that determine whether or not a child likes fruits and vegetables evolves in parallel with children's cognitive development, as well as their understanding and reasoning about health. The most important determinants of taste shift from appearance and texture attributes in 4- and 5-year-olds to more functional properties in 11- and 12-year-olds. Therefore, cognitive development parallels changes in the importance given to the attributes that determine whether or not a child likes fruits and vegetables, increasing their knowledge with age, along with development in the level of abstraction in reasoning and a better understanding of the health benefits of food. This finding could be of interest to those who design appropriate curricula and activities for the development of nutrition education in young children and should be incorporated into 
programs aimed at increasing the long-term intake of fruits and vegetables in children. Thus, using different preparation methods depending on the wishes of each specific age group, we could change children's fruit and vegetable preferences and, consequently, their intake [25]. These results are consistent with previous studies about the level of knowledge and thinking about the feeding process of children in the preoperational and concrete operational stages, which, according to Piaget, show characteristic differences, for example, in the use of symbolic thinking and in the skills required to demonstrate two-way and systematic thinking, as well as to analyze problems from multiple perspectives [34].

Children in Piaget's preoperative stage ( 2 to 7 years) are not yet fully developed cognitively and learn by imitating, investigating, asking questions, and comparing and classifying things around them. This is the stage when children learn basic concepts and begin to acquire the ability to think. Consequently, nutrition education can be difficult in the preoperative stage because children of this age have difficulties in understanding the relationship between nutrients and food, as well as the effects of food on the body. Therefore, at this stage it is not easy to understand and explain abstract concepts such as the definition of health or the importance of nutrition [22]. In general, classifications are commonly based on specific groups, such as drinks, main meals, and foods eaten together, rather than on abstract ideas such as constituent nutrients [35]. Furthermore, children of this age make appropriate groupings of fruits and vegetables, meat and derivatives, and sweet foods. Preschoolers begin to establish weak relationships between food and health and to recognize the need to maintain a varied and balanced diet, which is reflected in the food choices and comments they make. Thus, young children can indicate whether or not they like the taste of a product, but not identify the specific taste. For example, 4- and 5 -year-olds know and can properly use the taste of salt. When talking about sugar and salt they often comment on the similarities between the two substances in terms of appearance, stating that both of them are added to foods so that they taste 'better' or are 'bad', often mentioning teeth in this context [36]. However, they are not capable of doing so with other basic flavors.

Older children have a better understanding of the four basic tastes and are consequently more specific when discussing food tastes. At the age of 4 or 5 , they use concrete and simple 'rules' to classify products as healthy or not. The most popular justification rule is usually food color association, such as 'it's healthy because it's green', which can lead to misclassifications. Another argument is to link food groups and health, ('it's fruit and fruit is healthy') or preference ('it's healthy because I like it'). A surprising finding is that 4- and 5-year-olds argue that food is healthy because it tastes good, so it could be that young children associate healthy with tasty through the connection term 'good'; tasty food is good, just as being healthy is good too, until, at a certain age, the differentiation arises that not all healthy foods taste good [25]. At the age of 6, they present notions about the health consequences of food; know that specific nutrients, especially fats and sugar, have effects on the body; group foods as healthy or unhealthy and their selections are consistent with health views; and recognize that foods that are sweet or contain sugar or fats should only be eaten in small amounts and 'are bad', whereas those that contain fiber and vitamins are 'good' and 'healthy' [36,37].

It is not until the concrete operational stage that children include the presence of a specific nutrient to justify the classification of products as healthy or not, in addition to also mentioning 'the family says so' or 'I know it' [25]. The research carried out by Contento [38] on how children think about food and eating revealed that in the preoperational stage they did not distinguish between food and snacks, whereas children in the concrete operational stage did. In addition, the former thought that the ingested food entered the stomach and did not change in the body, whereas those of a specific stage indicated some type of change. The children in the preoperational stage were able to mention healthy foods, but not to justify this, and those in the concrete operational stage stated that food makes you strong, healthy, and grow, but were not able to explain it either. Schoolchildren between 7 and 11 years of age still make arguments that could lead to the restriction of potentially 
beneficial products, such as apples, because they are acidic or to consume unsuitable products, such as white chocolate instead of dark, considering that the second is not good only because it stains the teeth. Although they make correct classifications, sometimes the reasons used to do so are incorrect [35].

Therefore, the significant differences in global knowledge about food may reflect Piaget's stages of cognitive development and serve as a guide for the nutrition education of preschool children. Understanding that children's cognitive development is important for understanding and learning about the world around them would be helpful in designing effective and developmentally appropriate nutrition education in childhood [22]. Older children have a higher level of abstraction and are more aware of the health benefits of a good diet. Younger children have little understanding of the connection between food and the effect of fat intake and weight, which may contribute to current rates of childhood obesity [26].

\subsection{Acquisition of Nutritional Competence during Early Childhood Education}

The younger the children, the less established and externalized are their eating habits, so interventions in preschool children may be more effective than those in older ones. In addition, to increase its effectiveness, it is important to involve parents and caregivers, as well as train them to know the inherited habits in the eating behavior of children [31]. However, even though child nutrition education improves the behavior and lifestyle of preschoolers, nutritional interventions in schools with very young children ( 3 to 5 years old) are very scarce. Some studies aimed at developing the knowledge of healthy foods in parents of young children (5 to 6 years) [39] or promoting healthy behaviors among adults and preschool children [40] have shown that targeting the close environments of children achieves good results. The most effective school interventions are those that include the family and focus on realistic intermediate goals, for instance, linking changes in knowledge and attitudes towards diet and physical activity as early indicators of future improvements in adult cardiovascular health. In a study carried out in [41], parents and children were provided with a comprehensive nutritional education program for behavioral weight management and were encouraged to increase their intake of fruits and vegetables or decrease the consumption of fat- and sugar-rich foods. It was observed that directing the intervention to the intake of fruits and vegetables also resulted in a lower consumption of fats and sugars, whereas focusing on the reduction of fats and sugars did not improve the intake of fruits and vegetables. To avoid the childhood obesity epidemic, it is necessary to combine many strategies in schools, communities, clinics, workplaces, and homes [42].

A good opportunity to promote 'good habits' and support the effort made by teachers is to encourage the participation of families in the classroom. In this way, the commitment of all parents would help to promote nutritional knowledge and behaviors in the short and long term among preschool children and their families [43]. In addition, strategies focused on improving dietary and physical activity behavior must be combined with other critical aspects of an intervention program to be effective [44]. Likewise, it is recommended to include educational materials, films, and books that contain the widest variety of healthy foods as possible [31]. However, explaining nutrition and health to children, using terms that are too abstract for them to be understood and acquired (vitamins, minerals, nutritious foods, digestion, and risk of disease) is inappropriate. Therefore, incorporating Piaget's theory into nutrition education at an early age could have a lasting effect on eating behavior [22].

It is essential to promote adequate teacher training prior to the implementation of strategies to improve child health [45], since teachers are responsible for empowering students to interpret phenomena and to relate and connect knowledge, above all, promoting initiatives that allow them to extract the ideas that give meaning to the natural world [46]. España et al. [21] presented a frame of reference around seven dimensions for students to be competent in developing healthy habits and lifestyles regarding their diet. Among these, we can note knowledge about food; how the body works with regard to nutrition; 
cooking, growing, and making food; buying food; eating in company; physical activity; and rest. Other studies suggest participation in cooking classes and games, along with individual guidance to optimize diet and physical activity habits for children aged from 2 to 6 years [47].

A classroom curriculum that includes hands-on activities that emphasize gardening and nutrition, operationalized through strategies such as interactive stories, songs, dances, container gardening, snack preparation, and taste-testing activities promotes the learning of the origin of fruits and vegetables through active and observational learning, increasing the preference and intake of these foods among preschoolers. The children brought their plants and other materials they made home and shared them with their families, fostering dialogue between parents and children. In addition, at the end of the program, the parents were invited to an event in which the children presented songs and dances learned during the program [48]. This shows that the teaching activities developed in school gardens can relate science content to real-world contexts as relevant as the production of plant foods, also addressing the promotion of healthy eating habits [49]. The school garden as an educational resource allows teachers to develop with their students the skills related to scientific processes, such as making observations, classifications, measurements, predictions, or performing the identification of variables, among many others [50,51]. As a consequence, more and more educational centers are increasing their interest in having a school garden [52]. The selfproduction of fruits and vegetables is very useful for students since it involves activities that are not usually part of their daily experience: doing work outdoors, sharing natural resources, enabling cooperative work, and improving relationships between boys and girls $[51,53,54]$. The work of students and teachers in school gardens involves real practical activities based on experience, with which the learning of the curricular contents is facilitated and the skills typical of scientific work are put into practice, such as observation, the verification of ideas, as well as the perception and exploitation of proposals and actions [55].

Already during the 20th century, a similar resource, school preserves, was used to introduce a wide variety of practical knowledge and prepare students for life in a utilitarian sense. In addition, they allowed the teaching content to be related to the child's environment, organizing the school curriculum from a globalization and integration perspective that provides the opportunity to carry out research and promote curiosity, enabling the direct observation of phenomena and the acquisition of critical thinking and spirit [56]. Therefore, the use in educational centers of school gardens allows teachers to turn them into a very valuable educational space [49] and constitutes an opportunity for the classroom implementation of active and experiential methodologies [57]. With these gardens, students learn science by doing science through experimentation, developing knowledge, skills and attitudes typical of this field of knowledge [50,58].

\subsection{Proposal Justification}

As mentioned, it is essential to initiate students in the development of scientific competence from an early age. Through direct experiences, children interact directly with objects, which allows them to learn not only scientific content but also how knowledge is built. Specifically, if the intention is to promote familiarization with fruits and vegetables, it is necessary to offer students opportunities to learn about their diversity and promote a taste for them through appropriate sequences of activities for early childhood education.

Active teachers of 3- to 6-year-old children from different schools have expressed the importance of identifying preconceptions when teaching science in the early years. It is essential that lessons begin with an activity designed to identify preconceptions, as well as ending with another to summarize and discover if the initial predictions were correct [59]. Listening to what students are saying, even when answers are unexpected, is essential to select appropriate and meaningful activities that promote experiences that can be carried out directly by students and, whenever possible, to accommodate children's interests and develop their thinking [36]. Meanings can be better shared if we have a specific material to refer to, avoiding different interpretations of words because we have not experienced 
them directly. Starting from a concrete fact, dialogue can be promoted in the classroom through contact with reality. For example, to introduce the conditions that a seed needs to germinate, a good option is to start by talking about the different criteria that each child chose to make a bean germinate better at home. In this way, an everyday phenomenon until now is observed from a scientific point of view. This initial challenge promotes motivation by having to make active individual decisions to solve a problem, and finally, the sum of contributions will generate collective knowledge [46].

In school, when children begin learning new content about food, they already have their own ideas from their pre-school experience. Therefore, the introduction of new knowledge must be carried out through activities organized in a logical way that start from those ideas. Herein, we propose an educational intervention to promote the taste for healthy foods (fruit, vegetables, and legumes). The sequence consists of a set of differentiated activities that start from simple and concrete situations and progressively increase in complexity and abstraction [35]. This process allows a model to be built based on four key moments [60,61]:

(a) Verbalization of the initial models, so that the children formulate their own points of view (What do I know? What do I think? What do I feel? What do I do?) and recognize the objectives of the work through the analysis of very simple and concrete situations, close to the experiences and interests of the students. In addition, by sharing, children can be encouraged to overcome the self-centeredness of this stage by knowing that other children may have different points of view. It is necessary that the environment generated by the teacher be adequate and encourages children to be safe to verbalize their own thoughts.

(b) Activities to introduce new elements, relationships, and variables to identify new points of view and to confront reality (Are there other ways of seeing, thinking, feeling, and acting?). It is important to define the concepts and relationships between old and new knowledge. Depending on the content to be taught and taking into account the knowledge and interests expressed by the children in the previous stage, different methodological proposals could be included. In relation to feeding, educators will replace the existing schemes of children with the introduction of newly learned foods. As a result of assimilation through experience, children will gradually incorporate and adapt new concepts of nutrition [22].

(c) Structuring activities of the built models. It can be considered that learning has occurred when a child is able to communicate the elaborated models. For this reason, it is necessary for each child to personally elaborate their way of expressing knowledge, generalizing the new models built and contrasting them with those of other classmates. The way in which each child synthesizes the same learning and how confronts it with others is very diverse.

(d) Application activities of the developed model. The purpose of this is to facilitate the transfer of acquired knowledge to different situations, that is, to make it meaningful (How to apply new ways of seeing, thinking, feeling and acting?). Furthermore, its purpose is for children to be aware of what they have learned and to consolidate the new ideas.

We can conclude that, in order to design an adequate didactic sequence to teach science at this age, it is necessary for students to act personally and learn by observation, experimentation, classification, etc. These activities therefore require sufficient space and time according to the stage. Children learn best by doing, so it is important that educators promote the active participation of children in nutrition education, including drawings or games with nutritional content [22]. Considering the influence of social learning in this stage, activities that are carried out together with other classmates should also be incorporated. In this way, in addition to promoting the construction of new models, the development of social and communication skills is facilitated both by expressing their ideas orally and by means of drawings or diagrams, which are beginning at this age, and should progressively incorporate the characteristic language of science. This learning is guided 
by the teacher, who formulates the appropriate questions that should preferably be open, contextualized, and clearly formulated [62]. The questions must focus on observing the facts of the world in such a way that, taking into account the cognitive capacities of the children in the preoperative stage, they facilitate the development of the initial models towards others that are more intellectual, complex, and of a more general nature [63].

Through conversation and observation, we can also incorporate different forms of evaluation, such as self-evaluation, which will promote making children aware of what they have learned and self-regulating their learning [64]. In the preoperative stage, instead of using abstract nutritional concepts (nutrients that cannot be seen or touched), concrete statements and examples should be used. Choosing relevant activities (drawing, reading, discussion, hands-on activities) along with information that children already have will facilitate the acquisition of desirable nutritional concepts. In addition, explanations, classifications, and demonstrations can be used to help children remember what they have learned [22].

\subsection{Specific Objectives of the Work}

The global proposal is the development of competence in nutrition by preschoolers. Specifically, the work focuses on the following specific objectives:

- To initiate early childhood education students in the development of some of the most basic scientific skills in the context of nutrition, and more specifically of vegetables, such as making observations, manipulating simple instruments, putting into practice the design to be made, collecting data, and verbalizing their expectations and results.

- To understand the difficulties of children in early childhood education in carrying out basic scientific skills and propose guidelines for their development among early childhood education teachers.

- To promote the development of food competence through familiarization with fruits, vegetables, and legumes, as well as their care and the purposes of their cultivation.

\section{Materials and Methods}

\subsection{Sequence of Activities}

The activities developed to promote competence in food and care for the environment have been structured in a series of stages that are included in Table 1. Regarding the competence in food, the dimension that is analyzed in this study is the one related to the cultivation of fruits and vegetables.

Next, the activities in the stage of introducing new information (stage 2) are described in detail, along with images of the results. In this type of task, it is necessary for the teacher to ask good questions that allow students to carry out observations and scientific investigations based on data collected during practical experience, as exemplified in this text. The first activity of this phase is a proposal for early children to begin with the perceptual knowledge of the plants. The purpose is that the students know the diversity of seeds and understand that, because they are different, they will not grow in the same way and will give rise to a wide variety of fruits, vegetables, and legumes. This will allow us to expand the taste for these foods by learning about new varieties that can be introduced into our diet. The contents addressed are the following:

- $\quad$ There is a great variety of seeds.

- $\quad$ The seeds germinate and give plants.

- Different seeds will give rise to different plants (beans, lentils, chickpeas, broad beans, peas, and chard)

- Techniques for sowing seeds.

In the second activity in the same stage, 4- to 5-year-olds are initiated to observe how fruits, vegetables, and legumes change over time. Although the goal of this activity is not to make children aware of the passage of time, recording the days when changes occur is an approximation of understanding the cycles of the plants they are caring for. Specifically, the contents addressed are: 
- Changes that occur in the seeds during the germination process and its sequence.

- $\quad$ All plants have roots, stems, and leaves.

- Techniques that facilitate observation and data collection.

Table 1. Stages, objectives, and activities of the didactic proposal on the teaching of nutrition in early childhood education.

\begin{tabular}{|c|c|c|}
\hline $\begin{array}{c}\text { Stages of the Didactic } \\
\text { Sequence }\end{array}$ & Objectives & Performed Activities \\
\hline $\begin{array}{l}\text { Stage 1: Verbalization of the } \\
\text { initial models (initial } \\
\text { brainstorming activities) }\end{array}$ & $\begin{array}{l}\text { Express ideas about the new content } \\
\text { to be learned. } \\
\text { Be aware of the variability of } \\
\text { classmate's opinions. } \\
\text { Motivation to be interested in the } \\
\text { new learning. }\end{array}$ & $\begin{array}{l}\text { Go to the garden and talk about the plants to ascertain children's } \\
\text { preconceptions through questions formulated by the teacher. } \\
\text { Carry out discussions to find out the tastes for fruits and vegetables } \\
\text { among the whole group. } \\
\text { Stories or songs that arouse interest in schoolchildren. } \\
\text { Observe facts or images. } \\
\text { Promote the participation of families by sending fruits and vegetables } \\
\text { to be eaten and seeds of legumes to be grown at home. } \\
\text { Ask an open question, such as, How can we have more variety of fruits, } \\
\text { vegetables and legumes? }\end{array}$ \\
\hline $\begin{array}{l}\text { Stage 2: Activities to } \\
\text { introduce new elements, } \\
\text { relationships and variables } \\
\text { (confrontation with reality) }\end{array}$ & $\begin{array}{l}\text { Expand or transform initial ideas by } \\
\text { learning new information } \\
\text { Talk, practice, and think about science }\end{array}$ & $\begin{array}{l}\text { Practical observation/research work (activities } 1,2 \text { and } 3 \text { ). } \\
\text { Participation of families in the care of the plants, seeds, etc., that the } \\
\text { schoolchildren bring home. } \\
\text { Reading of materials adapted to the cognitive level (stories, webs). } \\
\text { Games. } \\
\text { Approach to situations or problems. } \\
\text { Information consultation (books, experts, internet). }\end{array}$ \\
\hline $\begin{array}{l}\text { Stage 3: Structuring activities } \\
\text { of the built models (reflection } \\
\text { and conclusions) }\end{array}$ & $\begin{array}{l}\text { Be aware of new learnings when } \\
\text { comparing them with initial ideas. } \\
\text { Co-evaluate learning with colleagues. }\end{array}$ & $\begin{array}{l}\text { Draw or talk about new ideas with the whole group. } \\
\text { Synthesis of what has been learned through a summary and reviewing } \\
\text { all the data collection tables of the germinations. }\end{array}$ \\
\hline $\begin{array}{l}\text { Stage } 4 \text { : Activities of } \\
\text { application of the elaborated } \\
\text { model (use of what has } \\
\text { been learned). }\end{array}$ & $\begin{array}{l}\text { Use the knowledge learned in new } \\
\text { situations and contexts. } \\
\text { Consolidate new ideas. } \\
\text { Check the learning functionality. } \\
\text { Talk, practice, and think about science. }\end{array}$ & $\begin{array}{l}\text { Draw what we have learned using different art techniques (see annex 3) } \\
\text { Games, songs, poetry (see annex 4) } \\
\text { Order the logical sequence of the life cycle of a plant (see annex 4) } \\
\text { Prepare a presentation to make to other classmates. }\end{array}$ \\
\hline
\end{tabular}

The materials needed for the implementation of this activity are different seeds (beans, lentils, chickpeas, broad beans, peas, and chard), pots or other containers, soil, water, and droppers or small bottles of water with a perforated cap. It is therefore necessary to make a series of concrete decisions with the students about the design of the experience, data collection, and analysis of results (choose the seeds, the container where they are placed, the place where it will be carried out, the environmental conditions, etc.). Next, the seeds are sown in the selected container and covered with soil, and water is poured until the soil remains moist but not flooded. The largest seeds (chickpeas, lima beans, and beans) should be soaked for at least $10 \mathrm{~h}$ before the activity. The students make observations and annotations on the data record sheets for about 15 days. In order to guide scientific observations, the teacher asks several questions during the experience:

a. How many plants have come out of each species?

b. How are they alike and how are they different (plant color, number, size and shape of the leaves, height, etc.)?

c. Are there differences between plants of the same type?

d. Have they all germinated at the same time? If not, what could be the cause?

To observe the process, seedbeds, which facilitate direct observation of the changes, are used, and each child cuts the cotton necessary for their own assembly. The cotton should be kept moistened but never flooded throughout the activity. It is convenient to use at least two containers with different seeds and try to rotate so that all the seeds have approximately the same amount of illumination. In this activity, although the technique does not allow many variations, there are some decisions to be made by the group such as the type of container and seeds, moments of observation, etc. Once the activity has been carried out, the data observed are recorded in the table (Figure 1). Subsequently, children 
interpret the data obtained and reflect on the similarities and differences of the changes produced in the different seeds.

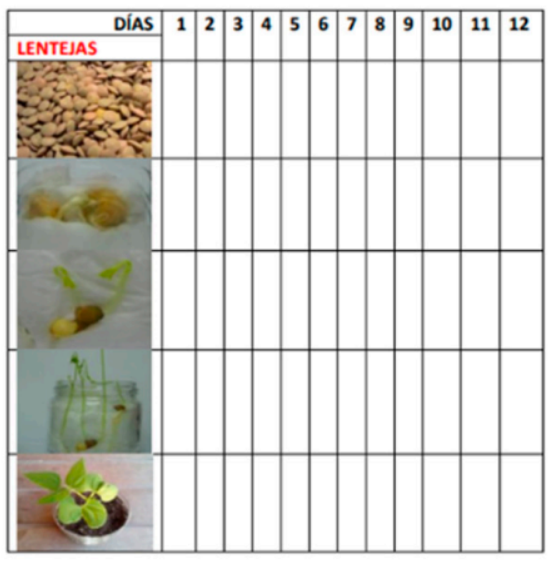

CRECEN ANTES LAS

TIENEN MÁS HOJAS LAS

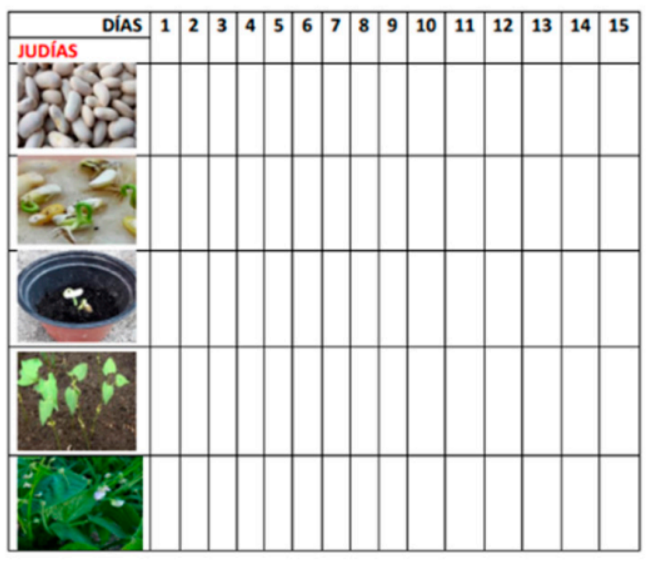

SON MÁS ALTAS LAS

SON MÁS DELGADAS LAS

Figure 1. Data recording table provided to children. (lentils/beans ... grow before ...... have more leaves ...... are the tallest ... are the thinnest).

The intent of the next activity from the same stage was that the students observe how the plants interact with the environment and take from it all the elements they need. To germinate, a seed requires water and air. It is also sensitive to temperature; however, light is not usually a factor that influences the process. There are also internal factors in the seeds (lethargy, longevity) that could influence their germination. In the early childhood education stage, the purpose is not to systematically investigate the environmental conditions that influence seed germination but rather to discover some of them. In the classes of 4- to 5-year-olds, we can provide students with experiences that facilitate the construction of that knowledge. The contents to work on are:

- The influence of some environmental conditions for the seeds to germinate.

- Initiation of research design.

The questions raised by the teacher during the activity are:

- How would you check if the water affects the germination of the seeds?

- How would you check if the light affects the germination of the seeds?

The experiment must specify both the variables that will be kept constant (container, number and type of seeds, lighting, place where it will be carried out, type of land where the seeds will be placed, etc.) and the values of the variable that are modified (watering twice a day or week/watering with the same amount of water once a day or week).

\subsection{Sample and Context}

The present research, which was manipulative and experiential, was carried out with an experimental group composed of an intentional non-probabilistic sample of 24 students (14 boys and 10 girls) aged 4-5 years that attended a school in a medium-sized capital city of Spain. In addition, a control group consisting of 14 students ( 7 girls and 7 boys) participated, with the same contents implemented, although the methodology and resources used were more traditional, based on predesigned materials and classroom work. The teacher set the working topics, proposed and guided the experiments, and exerted a leadership role. Two years ago, the school advised against the use of standardized textbooks in early childhood education. Since then, the teacher responsible for the group has provided their own educational material and has not been required to complete a specific book. Both 
teachers of the experimental and control groups had more than 20 years of experience in the profession and great dedication to their work, and it was the second year that they had worked with these students. In our study, the sequence was designed by the teacher of the experimental group, paying special attention to the suggestions made by the authors of this work. These activities were part of a project to promote healthy habits at school, which encouraged children to consume fruits and vegetables. For example, when they were 3-4 years old, they made fruit salads to learn about autumn fruits in a tasting activity that involved their families in the classrooms of the experimental and control groups.

Based on the teaching schedule, both teachers agreed on the objectives to be achieved and the contents to be developed (Table 2), although they followed different teaching approaches with greater use of the school garden and the selected pedagogical manipulative material in the experimental group. Despite having difficulties with respect to personal and material resources, the teacher of the experimental group opted for the aforementioned approach because the preschoolers showed a great interest in research and the natural environment. Moreover, this proposed instructional intervention was an attempt to create the conditions for children's active involvement with an aim of reconstructing their thinking at the precursor model level from a perspective close to the sociocognitive approach. Thus, it would help children to interact with the selected pedagogical material in appropriately designed environments $[65,66]$.

The implementation of the designed sequence of this study took place in the last trimester of the 2020-2021 school year. The center has a school garden, traditionally used by older students; however, the children in early childhood education showed great interest in getting to know the garden and participating in it, so for the first time it was included as part of the children's programming. At first, the decision was made to visit the garden to help clean the herbs and collect some vegetables, legumes, and fruits that were taken home to taste and grow with the families. Later, the activities were aimed at investigating seeds of different fruits and vegetables, germinating legumes, and planting edible sprouts in their own seedbed to see how they grow and to learn about the purposes of their cultivation once transplanted into the school garden.

All the activities were carried out in a practical and manipulative way, alternating between the classroom and the garden. The activities implemented in class were developed in four groups of six schoolchildren each. However, visits to the school garden were organized according to their availability, as there were usually students from higher grades using the garden. In addition, the coincidence in the schedule with the presence of a support teacher was used to carry out the activity with half of the students at a time. The intention was that students would enjoy natural resources and the outdoors, especially this year after having suffered enormous restrictions as a result of the pandemic.

\subsection{Evaluation}

For the learning evaluation of our proposal, we considered the techniques and instruments recommended in experiences for formative and shared evaluations in early childhood education [67]. Thus, photographs and video recordings of the sessions were collected. In these, the students can be observed carrying out the activities in small groups supervised by the teacher, whereas the rest performed another task. We also transcribed both the conversations held between the teachers and the students and the discussions between students. Moreover, both the children who did not participate in the program (control group) and the participants in this study were interviewed to compare the acquired competencies. The questions were agreed upon by all the study authors and were tested with 3 students to assess their suitability.

The evaluation of the teaching process was conducted through a self-reflection of the classroom teacher, taking into account the objectives achieved and the difficulties encountered, thus proposing improvements for future years. 
Table 2. Objectives, contents, and assessment criteria corresponding to the last trimester of the course, which correlated to the sequence of activities.

\begin{tabular}{|c|c|c|}
\hline Objectives & Contents & Assessment Criteria \\
\hline 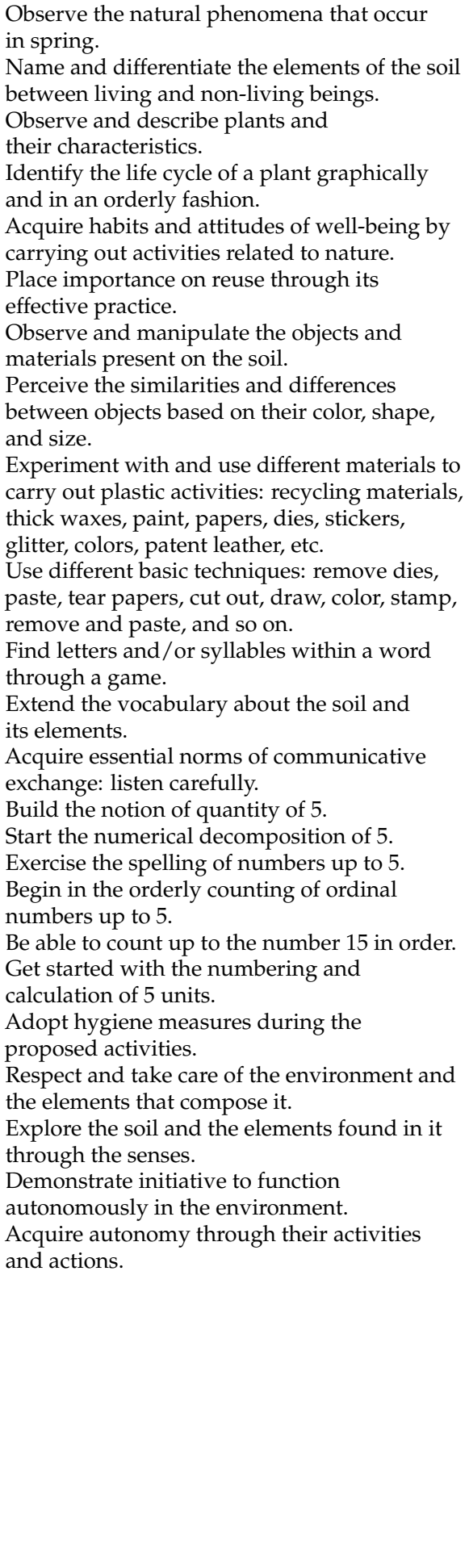 & $\begin{array}{l}\text { Observation of the phenomena of the natural } \\
\text { environment that occur in the spring. } \\
\text { Soil elements: living and non-living beings. } \\
\text { Observation of plants and description of } \\
\text { their characteristics. } \\
\text { Identification and serialization of the life cycle } \\
\text { of a plant. } \\
\text { Plant elements found in the soil. } \\
\text { Enjoy doing activities related to nature. } \\
\text { Reuse objects in the construction of } \\
\text { new objects. } \\
\text { Expansion of vocabulary about the soil: } \\
\text { insects, small animals, stones, roots, etc. } \\
\text { Basic rules of communicative exchange: } \\
\text { listen carefully. } \\
\text { Simple techniques of plastic expression: } \\
\text { painting, coloring, removing and pasting dies, } \\
\text { cutting and pasting, decorating, etc. } \\
\text { Materials for plastic expression: thick waxes, } \\
\text { colors, dies, stickers, paint, markers, glitter, } \\
\text { recycling materials, etc. } \\
\text { Importance of letter order: } \\
\text { attention/observation games. } \\
\text { Expansion of vocabulary about the soil: } \\
\text { insects, small animals, stones, roots, etc. } \\
\text { Narration of short stories from a sequence of } \\
\text { images: growth of a plant. } \\
\text { Numbers: quantity, spelling, and } \\
\text { decomposition. } \\
\text { Count to 15. } \\
\text { Initiation to addition. } \\
\text { Exploration of the soil and the elements found } \\
\text { in it through the senses. } \\
\text { Autonomy: actions and activities that they can } \\
\text { now do alone. } \\
\text { Initiative to function autonomously in the } \\
\text { environment.Attention and effort during the } \\
\text { performance of the various activities. } \\
\text { Hygiene and safety measures during the } \\
\text { ebservation and manipulation of objects and } \\
\text { forts environment. }\end{array}$ & 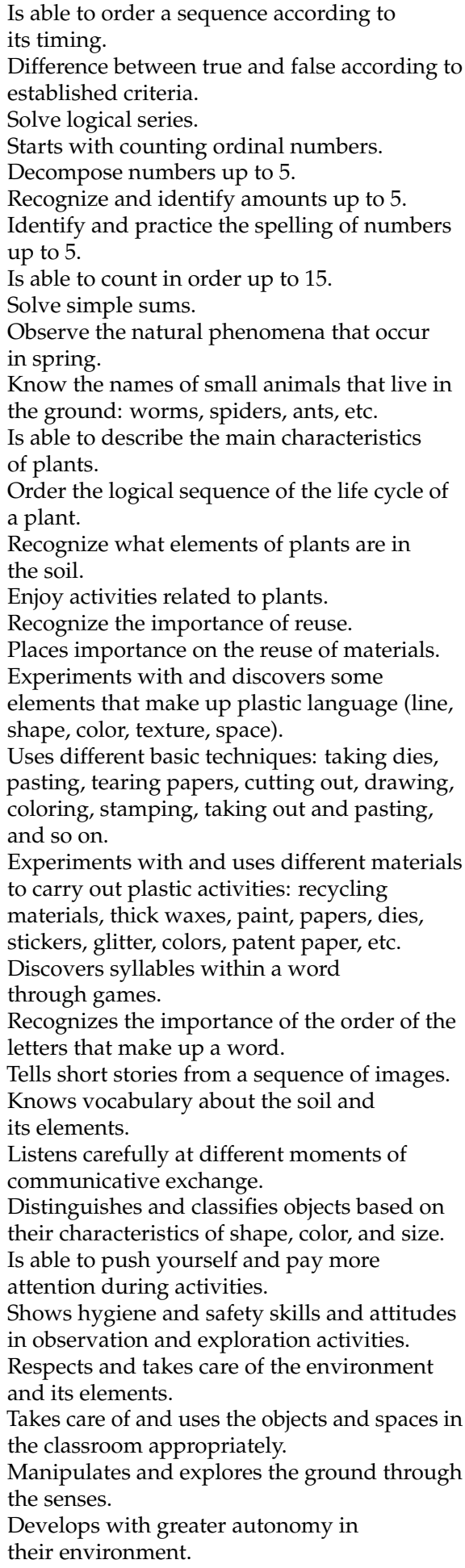 \\
\hline
\end{tabular}

\section{Results}

In the following sections, we differentiate between the students' productions and the opinions they expressed during the work in the following stages: (a) seedbed preparation; (b) plant growth, measurements and data collection; and (c) establishment of final conclu- 
sions by students after analyzing the information. Finally, we analyze the boys' and girls answers to different questions related to the acquisition of basic nutrition skills for this stage (d) and include the self-assessment of the teacher after implementing the sequence of activities in class (e).

\section{(a) Seedbed preparation}

During the development of the activities, the children were not asked to be silent, but were free to speak and move around the classroom. However, there were no misbehavior situations, and the teacher did not feel nervous with this format. Each had individual material to cut cotton, sow seeds, water and transplant from the seedbed of the group. In Figure 2 we show images of the students' scientific work.
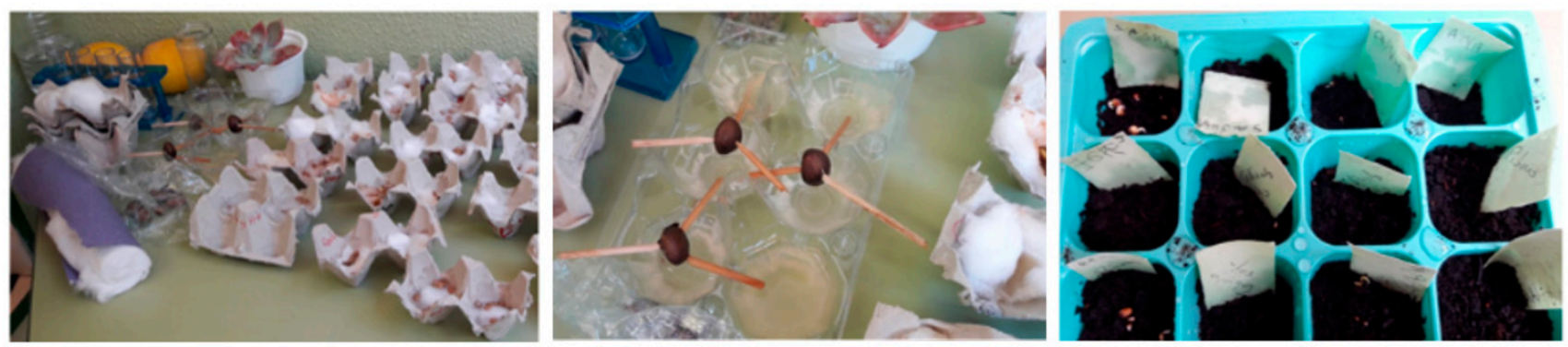

Figure 2. Seedbed preparation.

During the assignments, we wrote down the conversations of students and teachers about the work done. Certain doubts about the influence of light on the germination of the seeds and which was the most suitable place to place the seedbed were observed. Thus, Table 3 collects some of these conversations recorded during the development of the activity.

Table 3. Fragments of conversations between the teacher and the students throughout the seedbed preparation and plant growth of the educational intervention.

\begin{tabular}{cc}
\hline Teacher & Student \\
\hline Where do we put it? & In the closet \\
And if you don't get the light, what happens? & Does not grow \\
What are you doing? & Transplanting the pot \\
And what have you planted there? & Lentils \\
\hline
\end{tabular}

From the information collected in Table 3, we can observe that the students were expressing their ideas when answering the questions formulated by the teacher, for example, how the absence of light affects the growth of plants. We verified that the students were fully aware that they were working with plant seeds (lentils) and, although they may think that the seedbed will be more protected in a closed space (closet), they also believed that light was needed for germination, confusing this process with nutrition, a difficulty that has already been identified in other studies among primary education school students [68].

(b) Plant growth, measurements, and data collection

In the subsequent stages of the work, the students continued working under the same grouping conditions as in the previous stage. They also had at their disposal the individual material for watering, transplanting, measuring with a ruler, and collecting data. In addition, at this stage, they had a table to record the results of the growth of the plants throughout the days and, in this way, to establish comparisons between the plants of the same seedbed and the growth of the plants of other groups. Students made measurements using the ruler, collected data, and wrote them down in a table to compare the plants. In Figure 3 we show the germination of the seeds and the growth of the plants of some of the work teams. 


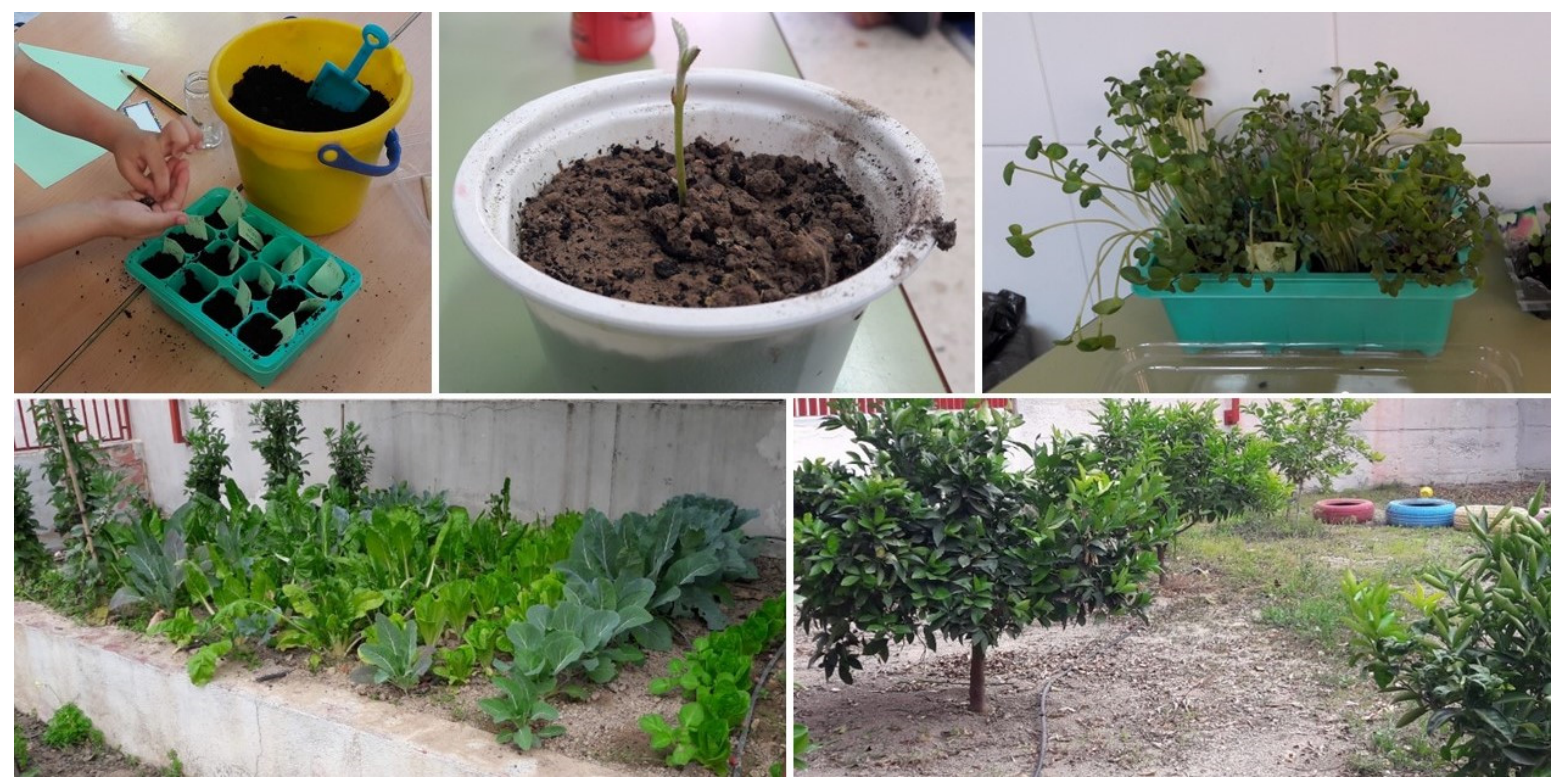

Figure 3. Plant growth.

One aspect of great interest in our work was verifying the need to begin in these stages of early childhood education with tasks, according to this level, that develop competence in measuring and recording systematic information. In Figure 4, we show images obtained in the class on the measurement of plant growth, as well as the recording of growth information over time.
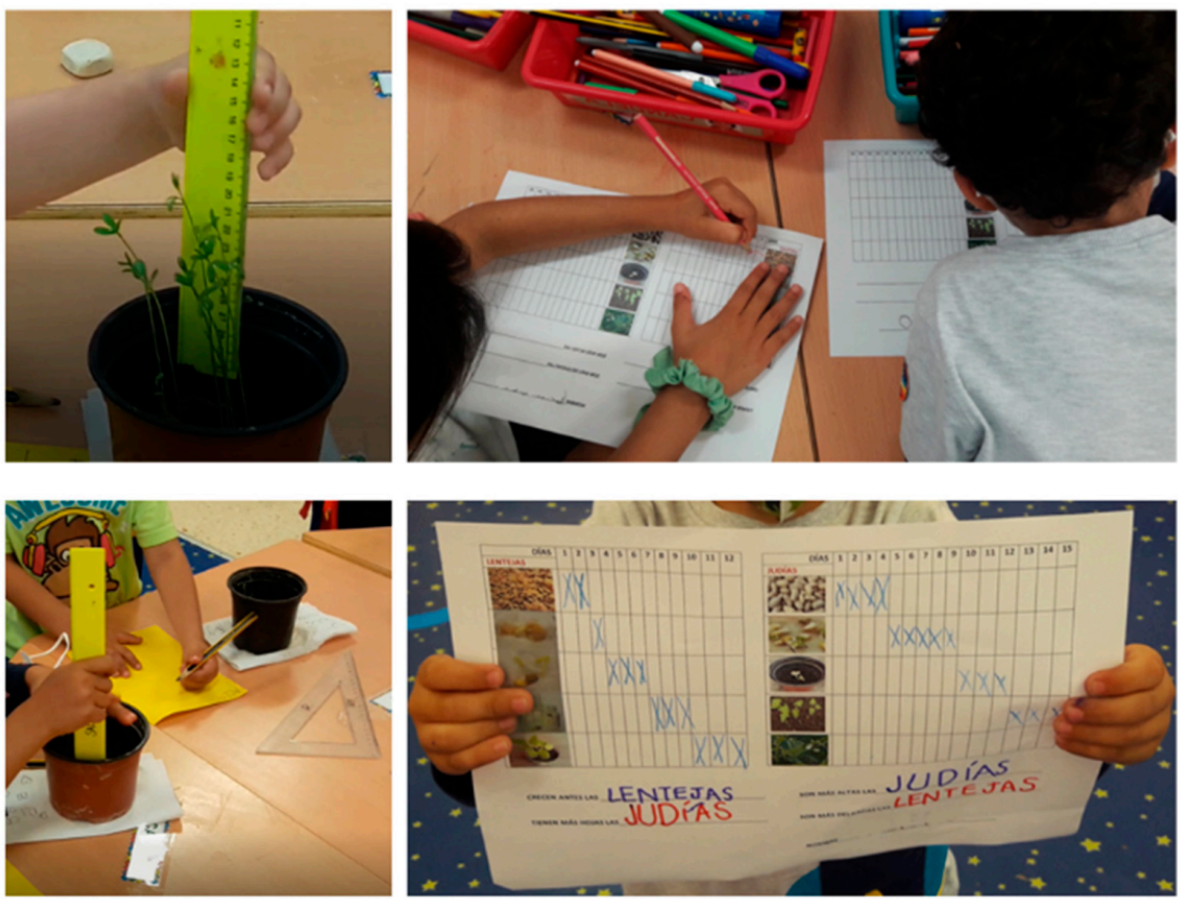

Figure 4. Plant growth measurements and data collection.

The analysis of the students' work and the recording of the conversations between the students and the teacher revealed some interesting aspects about the difficulties in making measurements and recording the information in tables. In Table 4, we include a selection of these conversations from the visualization of the videos and the answers collected. As shown in Table 4, it can be established that the activities promoted the learning of skills 
such as measuring the plants using a ruler, placing the zero at the same point, making comparisons between the different plants, and relating growth with planting time.

Firstly, we highlight the relevance, as it cannot be otherwise, of the importance of the measure to be able to specify some colloquial expressions of the students about growth. These were usually expressed with surprise at the growth, stating terms such as "it has grown a lot" or "it is very big", and they claimed the need to have a ruler to assess this growth and to be able to establish comparisons. In this regard, we also note the difficulties in using the ruler to make length measurements and, especially, the difficulty in making the zero of the ruler coincide with the point of origin of the plant in the pot. On the other hand, we also appreciate the students' interest in collecting the observed changes in plant growth in a data table, which allowed us to contrast the data between the teams. The teacher was very insistent on this aspect and the students generally followed these instructions.

Table 4. Fragments of conversations between the teacher and the students throughout plant growth, measurements, and data collection in the educational intervention.

\begin{tabular}{cc}
\hline Teacher & Student \\
\hline What is the length? & 17 \\
\hline Hi Pepe, what are you doing? & To size \\
\hline Have your plants grown a lot? & A lot \\
\hline How much? How high? & 11 \\
\hline $\begin{array}{c}\text { Well, write on your sheet, have they grown a lot? In how many } \\
\text { days? Then we will look at it on the table. }\end{array}$ & A lot \\
\hline
\end{tabular}

And how much have your plants grown? Have they grown a lot or a little?

Well, from last week to today it has been at least $4 \mathrm{~cm}$. Well, write it down and we will check it later. You planted them after the others.

\begin{tabular}{cc}
\hline $\begin{array}{c}\text { (The teacher gives him the rule) } \\
\text { Why is it better inside? }\end{array}$ & $\begin{array}{c}\text { Not like that, it's } \\
\text { better inside! } \\
\text { (No answer) A 1 and a 3. }\end{array}$ \\
\hline $\begin{array}{c}\text { And how are your plants? Have they grown a lot or a little? } \\
\text { like this, here is the zero. Write down that number. } \\
\text { And how are yours? } \\
\text { Quite large, just like Daniel's. }\end{array}$ & A lot \\
\hline It is wet? & A little big \\
\hline Well then add a little more & $\begin{array}{c}\text { (While watering) 'Already } \\
\text { or more?' No' }\end{array}$ \\
\hline
\end{tabular}

(c) Establishment of final conclusions by students after analyzing the information.

Collecting the information obtained with the video recordings of the classes and the analysis of the conversations allowed us to identify the evaluations that the boys and girls of our study population made about the diversity of data obtained and how they tried to justify that diversity of data. In Figure 5 we show some of the students' drawings once the tasks had been completed, in which they recreated their images of the work done.

Similarly, in Figure 6, we show other drawings and murals made by students who tried to summarize the experience. It should be noted that these works reflect the stages in the growth of plants from the moment they germinate until the end of the data collection in the classroom, allowing them to order the logical sequence of the life cycle of a plant.

Throughout this stage of the work, we verified the surprise that many of the students experienced due to the disparity of results found, with respect to the growth of plants. In Table 5, we show some examples of teacher and student conversations that reflect this variety of data. 

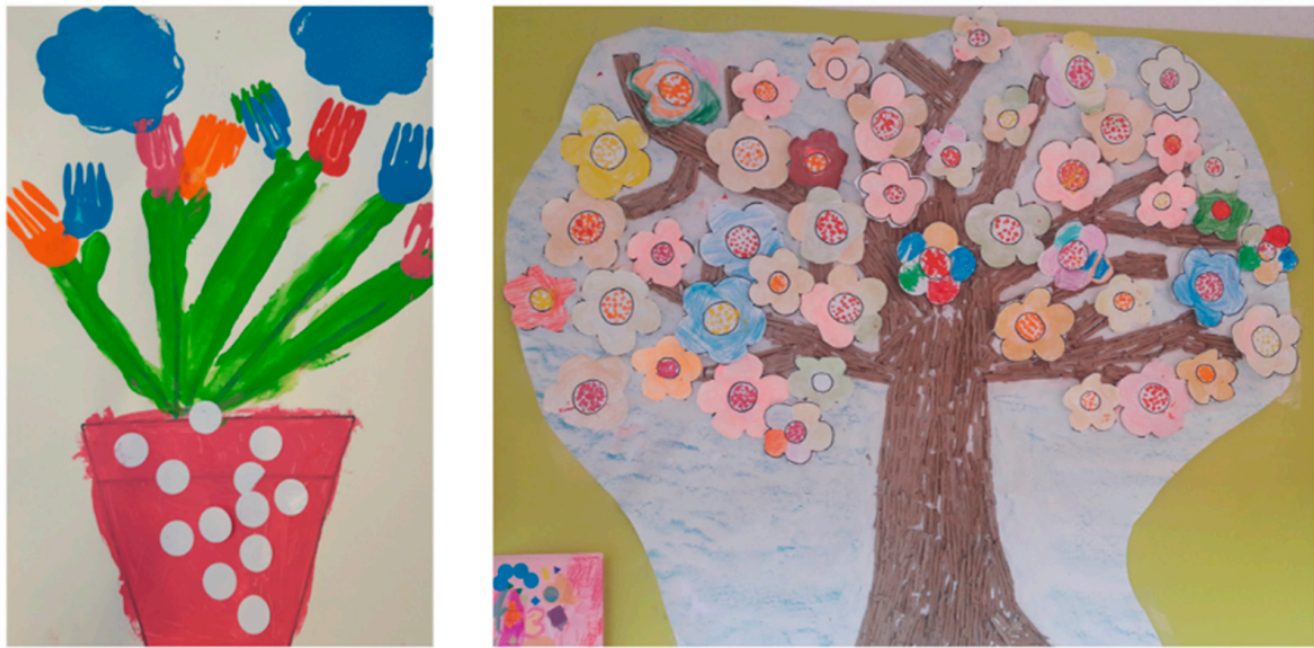

Figure 5. Drawings of what children had learned using different art techniques.
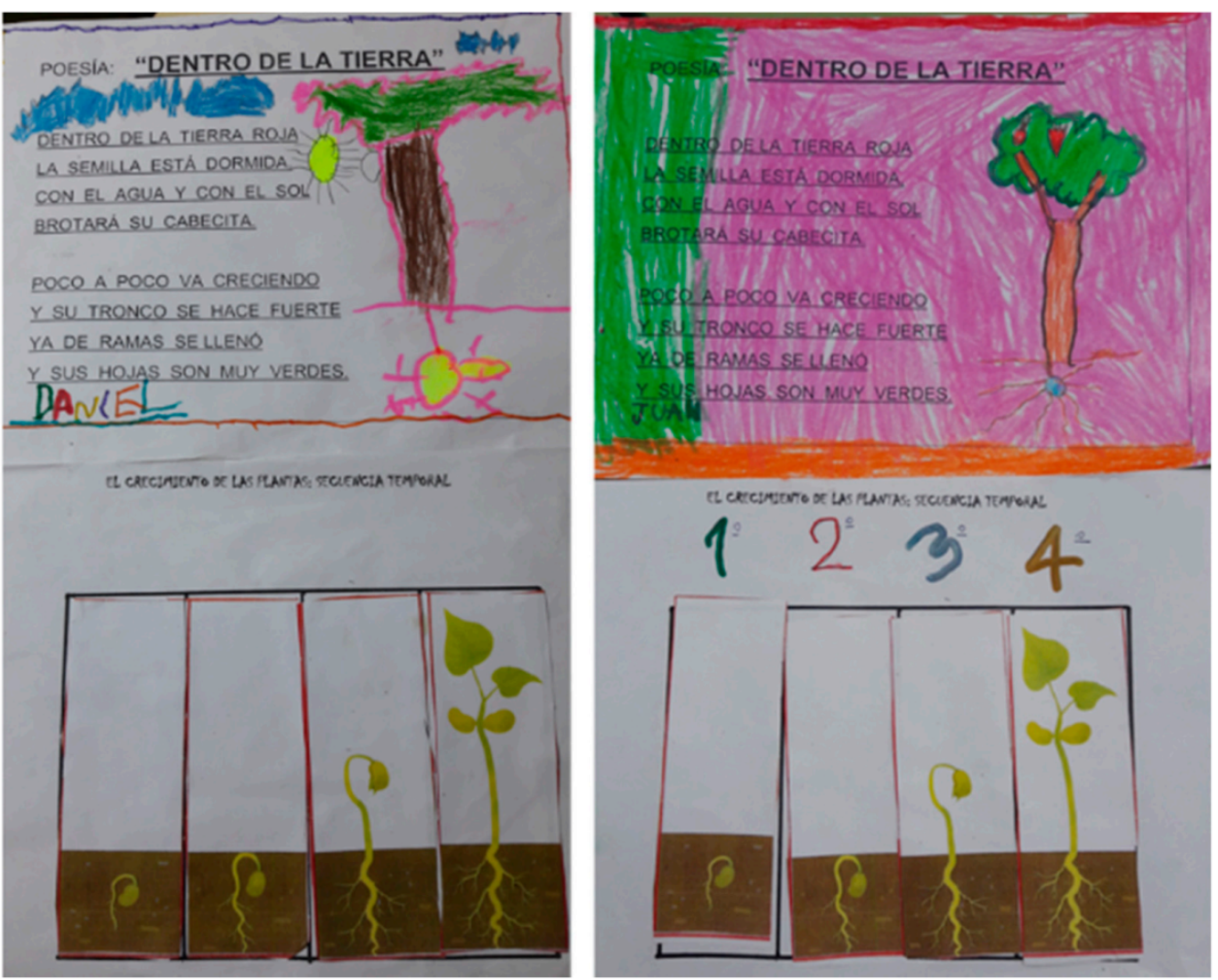

Figure 6. Poetry ("Inside the red earth, the seed is asleep; with the water and the sun, its little head will sprout. Little by little it grows, and its trunk becomes strong. It has already filled with branches, and its leaves are very green") and time sequence of the life cycle of a plant's growth.

The students showed surprise when they appreciated that between the seeds that they had planted themselves, simultaneously in the same container, there were disparate growths. Others, in addition, also expressed their confusion about the fact that other groups of students obtained different growths. These ranges in growth, which for scientists fall within normality, surprised these children for the first time, providing them with an interest in learning about science. On the other hand, we also identified interesting reflections on whether or not one's expectations were met with respect to expected growth. We consider 
that this variety of outcomes not initially expected by students is an important reason to justify the need for these records of information, even at these very young ages.

Table 5. Fragments of conversations between the teacher and the students on the results obtained in the work of the educational intervention.

\begin{tabular}{cc}
\hline \multicolumn{1}{c}{ Teacher } & Student \\
\hline $\begin{array}{c}\text { Well, yours have grown. And many have come out. } \\
\text { You've taken good care of them, haven't you? }\end{array}$ & Mine have grown, but less. \\
\hline $\begin{array}{c}\text { And what happened to yours? Do they all } \\
\text { measure the same? }\end{array}$ & No \\
\hline $\begin{array}{c}\text { And yours? How much? } \\
\text { Well, tell him to lend it to you }\end{array}$ & $\begin{array}{c}\text { Mine have grown a lot! } \\
\text { But if I don't have any ruler }\end{array}$ \\
\hline Who has the tallest plants on this team? & Ángela \\
\hline
\end{tabular}

Finally, it could be observed that through familiarization activities with fruits, vegetables, and legumes, the students learned new scientific content and developed research skills. The children were able to recognize the diversity in fruits, vegetables, and legumes, the changes that take place in them during their life cycle, and how they interact with the environment that surrounds them. The teacher recognized the effectiveness of the activities in motivating the students to acquire knowledge about the environment, as well as in developing the ability to integrate content from other areas with meaning for the students, such as counting, reading, writing, and the arts. Therefore, it is considered necessary to continue with this type of proposal, reducing the use of decontextualized and meaningless files.

(d) Answering the questions included in the interviews.

In Table 6 we present some examples of the responses obtained in interviews with children from both the experimental and control groups after carrying out the activities. The interview was semi-structured in order to guide and promote the expression of their ideas.

Table 6. Answers obtained from semi-structured interviews *.

\begin{tabular}{|c|c|c|}
\hline & Experimental Group & Control Group \\
\hline Questions & 9 Girls, 8 Boys & 7 Girls, 7 Boys \\
\hline Have you ever planted? & Yes (17) & Yes (7)/No (2)/I do not remember (5) \\
\hline What have you planted? & $\begin{array}{c}\text { Examples: Trees, plants, bulbs, all fruit and all } \\
\text { vegetables, food, seeds, flowers, beans, } \\
\text { oranges, pears, lemons, all kinds of things, } \\
\text { broccoli, onions, tomatoes, black grapes, } \\
\text { kidney beans }\end{array}$ & $\begin{array}{l}\text { Examples: Watermelons, cherry tomato, mint, } \\
\text { strawberry, flower, tomatoes, bananas, seed, } \\
\text { tangerine, orange, apple, lemon, carrot, lettuce, } \\
\text { beans, apple, pear, cucumbers }\end{array}$ \\
\hline Where? & In the school garden (17), home (6) & $\begin{array}{c}\text { At home, a family member's garden, } \\
\text { after-school activity }\end{array}$ \\
\hline Why do you think they are planted? & $\begin{array}{c}\text { Eat }(10), \text { grow plants }(6), \text { nice garden }(2) \text {, so } \\
\text { that there are more trees }(1)\end{array}$ & $\begin{array}{l}\text { To catch them and eat them (4), so that they } \\
\text { grow up (2), I don't know (2), so that my } \\
\text { grandfather can get good (1), for my } \\
\text { grandparents (1), to grow plants (1), so that } \\
\text { they do not break (1), so that they have sisters } \\
\text { and are not alone (1), because it was the first } \\
\text { time (1), to eat them in summer (1), to make } \\
\text { the environment (1), to take them when they } \\
\text { turn yellow and green (1) }\end{array}$ \\
\hline $\begin{array}{l}\text { Where do the fruits and vegetables we eat } \\
\text { come from? }\end{array}$ & $\begin{array}{l}\text { From the garden (10), from the trees (3), from } \\
\text { the land (1), from the plants (1), } \\
\text { I don't know (1) }\end{array}$ & $\begin{array}{l}\text { We buy them in a supermarket (3), I don't } \\
\text { know (2), of the plants (2), of the trees (2), of } \\
\text { the leaves of the plants (1), they arrive in a car } \\
\text { at the store (1), of the orchard (1), from a seed } \\
(1) \text {, a flower comes out of the seed, I have not } \\
\text { seen it but I have told you (1) }\end{array}$ \\
\hline
\end{tabular}


Table 6. Cont.

\begin{tabular}{|c|c|c|}
\hline & Experimental Group & Control Group \\
\hline Questions & 9 Girls, 8 Boys & 7 Girls, 7 Boys \\
\hline And did you like to eat it? & $\begin{array}{l}\text { Yes (17) } \\
\text { Examples: cucumber, broccoli, cauliflower, } \\
\text { carrot, apple, watermelon, grapes, banana, } \\
\text { orange, pear, tangerine, strawberry }\end{array}$ & $\begin{array}{c}\text { Yes (14) } \\
\text { Examples: apple, banana, watermelon, nuts, } \\
\text { strawberry, tangerine, orange, carrot, tomato, } \\
\text { grape, peach, salad, pear, persimmon, } \\
\text { strawberry yogurt }\end{array}$ \\
\hline $\begin{array}{l}\text { Why do you think we have to eat fruit and } \\
\text { vegetables? }\end{array}$ & $\begin{array}{l}\text { To be healthy (6), to be strong (5), not to get } \\
\text { sick ( } 3 \text { ), because I like it (2), to get older (1), so } \\
\text { that our body is well (1), for desserts (1), to } \\
\text { have vitamins (1), I don't know (1) }\end{array}$ & $\begin{array}{l}\text { So that we are strong (5), because it is healthy } \\
(5) \text {, to get healthy (2), not to get sick (2), } \\
\text { because we get big/grow (2), it is a fruit (1), it } \\
\text { has nutrients that are good (1), to be well (1), } \\
\text { not eat anything bad (1), because they are } \\
\text { good for the stomach (1), because they are } \\
\text { vegetables (1), if we do not eat vegetables we } \\
\text { get fat (1), to eat (1), because they have } \\
\text { vitamins but don't know what it is (1), because } \\
\text { I am very hungry (1), it is healthier than bad } \\
\text { things (1), so as not to get fat (1), healthy } \\
\text { means that you have to eat it (1) }\end{array}$ \\
\hline What do we plant for? & $\begin{array}{c}\text { So that later we can eat them }(16) \text {, so that it } \\
\text { grows }(4) \text {, so that there are many trees (1), } \\
\text { for the fruit (1) }\end{array}$ & $\begin{array}{c}\text { To later eat it them (6), I don't know (2), to } \\
\text { have strength (1), to get thinner (1), to get } \\
\text { bigger (1), to grow plants and sometimes come } \\
\text { out with fruits (1), so that they are born } \\
\text { because if not, the flowers would not live in } \\
\text { spring (1) }\end{array}$ \\
\hline
\end{tabular}

* The value in parentheses corresponds to the number of children who gave this answer.

The affirmative or negative answers were not counted when the interviewer explained the answer to the question if any student did not answer. For example, if they did not answer "Why did we plant?" and the interviewer indicated the answer, the students tended to agree; however, the answer was not counted. On the other hand, some questions had more answers than students, when one of them mentioned more than one aspect.

As concluded from the interviews, knowledge is acquired from contexts other than school, such as the children's families. The children in our sample expressed ideas as a result of observation and interaction with the world around them. However, sometimes these ideas deviated from scientific ideas. The formative intervention through direct experience with fruits and vegetables led to the development of more scientific ideas about food competence in early childhood education.

The students from the experimental group, who worked in the school garden, tended to say that "we go to the garden, we pick up the food, and then we go home and eat it", a fact that may have contributed to promoting a greater association between garden care and the promotion of healthier eating. Some of them said that "each child plants their favorite fruit in the garden", which could help them become familiar with more fruits and know about the tastes of the rest of their classmates. In addition, they recognized that they eat fruits because "José Antonio (teacher) has given me a mandarin to take home and eat it". They also mentioned aspects such as "to plant you have to grow a seed" or "if you eat an orange that has already left the orchard and has a seed, it may be a seed", so they already have knowledge about the plant cycle, since they know about seeds. They recognized the importance of caring for the environment since "the garden remains beautiful and with beautiful trees and so when we want to go to the garden the more we go, the more trees there are. One day we find a plant in a bottle, but it was small, it had not yet been born. It was dry, nobody took care of it, we took it to class and José Antonio took care of it, so we poured water on it so that it would grow more and so on. When it grows we leave it in the garden". Other times, most students from the control group alluded to facts that they knew even if they had not observed them. For example, "a flower comes from the seed, I have not seen it but I have already told you" because these contents were also studied as part of the training program in this group. Furthermore, in the experimental group there was a 
slight improvement in the association between the plants of the school garden and the food, undoubtedly influenced by the experience of planting and caring for the plants at school. In the interviews, the majority indicated that the garden plants had been planted to feed us and, consequently, the majority related the fruits and vegetables they consumed with their origin in a garden. However, in the control group, the responses to these questions presented a greater variety, for example, the selection of "strawberry yogurt" as a fruit they like to eat, a reflection that this association is achieved to a lesser extent.

In both classes, healthy habits had started to develop, as all the interviewees answered that fruit and vegetables should be eaten. In relation to the term healthy, they did not know its exact meaning but they had ideas, such as that certain foods are healthy "because they are vegetables" or "because I like it", using concrete rules to classify them, such as the family they belong to or their own food preferences [25]. In some cases, they mentioned that "healthy food is rich food and it is for you to have more strength" or that fruits and vegetables have nutrients or vitamins, but that they did not know their meaning, or simply that they must eat them because they are fruits or vegetables. These results demonstrate that food classifications based on constituent nutrients are too abstract for these ages [35].

(e) Teacher self-assessment.

The teacher highlighted the possibility of achieving the objectives of observing nature and its characteristics from a "scientific" perspective in a very gratifying way for both the children and himself, since the children were free to choose the activities they performed. On the other hand, they experienced a lack of materials (a single seedbed for the whole class instead of one per group), space, time, and human resources. For future years, the teacher requested the amplification of the material assigned to each group, an increase in the area of the garden so that it could be used by more students, allowing more time for the activities to be able to conduct them in greater depth, and the use of a support teacher to carry out alternative activities with the students who are not in the garden at the time.

\section{Discussion and Educational Implications}

The problem of childhood obesity, which has been increasing in alarming proportions in recent years [69], must be attacked in a key setting, the school. Thus, personal experiences of students regarding the cultivation and care of plants (which they associate with food) might favor an increased preference for and intake of fruits and vegetables, which may reduce the risk of chronic disease development associated with diet [48]. In this way, this work has addressed some of the aspects that must be considered in the educational field from the first stage of school, such as early childhood education. We present an example of some activities necessary to promote familiarization with fruit and vegetables, along with the initial development of certain essential skills required for preschoolers to acquire food competence. Specifically, the following results should be highlighted:

- In accordance with our first objective of initiating early childhood education students in the learning of some basic scientific skills, we verified that the development of competence in food must be carried out throughout the school stage, so it is necessary to incorporate more activities that address other contents, such as the classification of foods, the observation of their characteristics, or taste-tasting activities. Due to the limited intervention that we carried out, we do not intend to generalize our results to the entire preschool population. However, we did see important differences between the schoolchildren who followed the designed activities and the control group of the same age and school. In this way, we consider that the students from the experimental group began to acquire the basic scientific competences related to plant foods (observing, measuring, and food competence).

- The identification of difficulties in the development of such competences, as we established in our second specific objective, needs special attention. According to the monitoring of the germination and growth of the plants in data tables, we were able to verify that this was a skill that required greater dedication from the teacher in order 
to ascertain that the task was carried out and to resolve of the doubts that could be raised. Nevertheless, we consider that it is of great importance for the beginning, even if it is incipient, of systematic work in this area.

- As has been noted, it was possible to transfer to the usual classroom some of the basic tasks for the development of these skills. Thus, as a consequence, in relation to our third more specific objective regarding the care and cultivation of vegetables and legumes by schoolchildren, we consider it of great importance that educational centers have a school garden in which activities for preschoolers can be planned, allowing content related to obtaining healthy foods and the possibility of trying them, both at school and at home, to be addressed. In this way, the work in the school garden allowed preschoolers to relate plant food with living beings and their origin. In addition, the design and implementation of the sequence of activities from the competence framework allowed us to select content related to food relevant to children in early childhood education through a vocabulary that is understandable and appropriate to the child's cognitive stage. These activities, together with the promotion of collaboration between educational centers and families, promote the development of competence in nutrition in early childhood education. On the contrary, in the control group, some students had difficulties in establishing the origin of plant foods ("We buy them in a supermarket"), in accordance with results reported by other international studies [70], whereas this statement was not made by any of the students in the experimental group.

- Moreover, it is necessary to emphasize that the experience was a success for both the teacher and the students. Therefore, it has been proposed to extend the implementation to the rest of the early childhood classes in the next academic years.

Finally, it is worth mentioning current recommendations for influencing children's healthy behavior patterns, which suggest acting in various sectors. With regard to food, it is known that the commercial sector has a great influence on children, so it is essential to have adequate proposals to educate children in health-related areas. The design of useful interventions for children between 4 and 6 years of age, which aim to help parents and educators to positively influence the body weight of young children through adequate nutrition, requires further consideration and represents an area of fast-growing research. For future studies, children's reasoning about food should be explored in depth, especially their reasoning in regard to 'healthy' and 'unhealthy' groups [26] and how the concept of health is developed during the childhood years [25]. Thus, it is of great importance that educators consider the differences found in the conceptual understanding of health and nutrition in young children, making it necessary for teachers to base the curricula on the children's cognitive development levels. Moreover, people's eating patterns are determined by their exposure to certain actions, as well as their own personal choices. Knowledge, perceptions, and decisions to select a food can have a significant impact on interventions aimed at changing food intake and preferences. It is necessary to incorporate activities that allow students to know and become familiar with different types of fruits, vegetables, and legumes through direct manipulation. In this way, children begin the development of scientific competence through the teacher's guidance and the formulation of appropriate questions.

To summarize, in order to complete the development of food competence, an issue of great importance for our schoolchildren, multiple approaches that complement the work carried out in schools are required.

- Parents should be educated on the fundamentals of healthy eating and physical activity and be involved in school initiatives. Furthermore, schools must educate students on healthy eating and practical skills to achieve adequate nutrition, developing a program that reaches homes and incorporates peer teaching. Likewise, it is highly recommended that fresh fruits and vegetables are available daily, preferably for free.

- $\quad$ It is necessary to encourage daily physical activity, both inside and outside of school. In addition, politicians should promote initiatives that encourage programs to promote 
employee and family health; establish physical activity facilities in the workplace; modify the built environment to encourage physical activity; and spread health messages [42].

- The medical community can also collaborate by promoting effective counselling for families, as well as developing resources to complement this, and governments must also implement more effective measures than the current self-regulatory systems, in order to counteract distorted advertising information offered by the media [71].

Author Contributions: Conceptualization, L.L.-B., M.M.-C. and G.E.A.F.; methodology, J.A.M.R. and L.L.-B.; software, L.L.-B., M.M.-C. and G.E.A.F.; validation, L.L.-B., M.M.-C., G.E.A.F. and J.A.M.R.; formal analysis, L.L.-B., M.M.-C. and G.E.A.F.; investigation, J.A.M.R. and L.L.-B.; resources, , J.A.M.R. and L.L.-B.; data curation, J.A.M.R. and L.L.-B.; writing-original draft preparation, L.L.-B.; writing-review and editing, L.L.-B., M.M.-C. and G.E.A.F.; visualization, L.L.-B., M.M.-C. and G.E.A.F.; supervision, L.L.-B., M.M.-C. and G.E.A.F.; project administration, J.A.M.R.; funding acquisition, L.L.-B. All authors have read and agreed to the published version of the manuscript

Funding: This work has been partially financed by the project PGC2018-097988-A-I00 funded by FEDER/Ministry of Science and Innovation (MCI) of Spain- State Research Agency (AEI).

Institutional Review Board Statement: The study was conducted in accordance with the Declaration of Helsinki, and approved by the Institutional Review Board (or Ethics Committee) of University of Murcia (protocol code 2083/2018).

Informed Consent Statement: Informed consent was obtained from participating classroom teachers of children involved in the study.

Data Availability Statement: The data presented in this study are available on request from the corresponding author.

Acknowledgments: This work would not have been possible without the participation of CEIP Santa María de Gracia (Murcia) students, their teachers and all personal equipment, who facilitated entry into their classrooms. Without them, the research would be meaningless. We also want to thank the in-service teachers Lola and Natalia for the feed-back received.

Conflicts of Interest: The authors declare no conflict of interest. The funders had no role in the design of the study; in the collection, analyses, or interpretation of data; in the writing of the manuscript, or in the decision to publish the results.

\section{References}

1. Duschl, R. Renovar la Enseñanza de las Ciencias. Importancia de las Teorías y su Desarrollo; Narcea: Madrid, Spain, 1997.

2. Harlen, W. Enseñanza y Aprendizaje de las Ciencias; Morata-MEC: Madrid, Spain, 1989.

3. Hodson, D. Redefining and Reorienting Practical Work in School Science. Sch. Sci. Rev. 1992, 73, 65-78.

4. Lawson, A.E. Uso de los ciclos de aprendizaje para la enseñanza de destrezas de razonamiento científico y de sistemas conceptuales. Enseñanza De Las Cienc. 1994, 12, 165-187. [CrossRef]

5. Jiménez Aleixandre, M.P.; Sanmartí, N. ¿Qué ciencia enseñar? Objetivos y contenidos en la educación secundaria. In La Enseñanza y el Aprendizaje de las Ciencias de la Naturaleza en la Educación Secundaria; ICE/Horsori: Barcelona, Spain, 1997; pp. 17-45.

6. OECD. PISA 2006: Marco de la Evaluación. Conocimientos y Habilidades en Ciencias, Matemáticas y Lectura. 2006. Available online: http:/ /browse.oecdbookshop.org/oecd/pdfs/free/9806034e.pdf (accessed on 20 May 2021).

7. Chamizo, J.A.; Izquierdo, M. Evaluación de las competencias de pensamiento científico. Alambique 2007, 51, 9-19. [CrossRef]

8. Franco, A.J. Competencias científicas en la enseñanza y el aprendizaje por investigación. Un estudio de caso sobre corrosión de metales en secundaria. Enseñanza De Las Cienc. 2015, 33, 231-252.

9. Harlen, W. Science as a key component of the primary curriculum: A rationale with policy implications. In Primary Science, Wellcome Trust Education: London, UK, 2008; ISSN 1758-7956. Available online: www.wellcome.ac.uk/perspectives (accessed on 20 May 2021).

10. Harlen, W. The Teaching of Science in Primary Schools; Taylor \& Francis Ltd.: London, UK, 2018.

11. Osborne, J.; Dillon, J. Science Education in Europe: Critical Reflections; Nuffield Foundation: London, UK, 2008.

12. Sesto, V.; García-Rodeja, I. How Do Five- to Six-Year-Old Children Interpret a Burning Candle? Educ. Sci. 2021, 11, 213. [CrossRef]

13. Riegle-Crumb, C.; Morton, K.; Moore CChimonidou, A.; Labrake, C.; Kopp, S. Do Inquiring Minds Have Positive Attitudes? The Science Education of Preservice Elementary Teachers. Sci. Educ. 2015, 99, 819-836.

14. Kang, J.; Keinonen, T. The effect of inquiry-based learning experiences on adolescents' science-related career aspiration in the Finnish context. Int. J. Sci. Educ. 2017, 39, 1669-1689. [CrossRef] 
15. Criado, A.M.; Cruz-Guzmán, M. ¿Cómo mejorar la educación científica de Primaria en España desde el currículo oficial? Sugerencias a partir de un análisis curricular comparativo en torno a las finalidades y contenidos de la Ciencia escolar. Enseñanza De Las Cienc. 2014, 32, 249-266.

16. Ravanis, K. Early childhood science education: State of the art and perspectives. J. Balt. Sci. Educ. 2017, 16, 284-288. [CrossRef]

17. Siry, C.; Ziegler, G.; Max, C. “Doing science" through discourse-in-interaction: Young children's science investigations at the early childhood level. Sci. Educ. 2012, 96, 311-326. [CrossRef]

18. García-Carmona, A.; Criado, A.M.; Cañal, P. Alfabetización científica en la etapa 3-6 años: Un análisis de la regulación estatal de enseñanzas mínimas. Enseñanza De Las Cienc. 2014, 32, 131-149. [CrossRef]

19. Cañal, P. La alfabetización científica en la infancia. Aula De Infant. 2006, 33, 5-9.

20. Spektor-Levy, O.; Kesner, Y.B.; Mevarech, Z. Science and Scientific Curiosity in Pre-school. The teacher's point of view. Int. J. Sci. Educ. 2013, 35, 2226-2253. [CrossRef]

21. España, E.; Cabello, A.; Blanco, A. La competencia en alimentación. Un marco de referencia para la educación obligatoria Enseñanza De Las Cienc. 2014, 32, 611-629. [CrossRef]

22. Başkale, H.; Bahar, Z.; Başer, G.; Ari, M. Use of Piaget's theory in preschool nutrition education. Rev. De Nutr. 2009, 22, 905-917. [CrossRef]

23. González-González, A.; Falero-Gallego, M.P.; Redondo-González, O.; Muñoz-Serrano, A. Patrón dietético de la población escolar del Área La Mancha-Centro (Ciudad Real). An. De Pediatría 2016, 84, 133-138. [CrossRef]

24. Harris, G.; Coulthard, H. Early Eating Behaviours and Food Acceptance Revisited: Breastfeeding and Introduction of Complementary Foods as Predictive of Food Acceptance. Curr. Obes. Rep. 2016, 5, 113-120. [CrossRef]

25. Gertrude, G.Z.; Koelen, M.A.; Kok, F.J.; de Graaf, C. Cognitive development and children's perceptions of fruit and vegetables; A qualitative study. Int. J. Behav. Nutr. Phys. Act. 2007, 4, 30. [CrossRef]

26. Xu, T.; Jones, I. An Investigation of Children's Understanding of Food and Nutrition. Early Child. Educ. J. 2016, 44, 289-297. [CrossRef]

27. O'Connor, G.; Fragkiadaki, G.; Fleer, M.; Rai, P. Early Childhood Science Education from 0 to 6: A Literature Review. Educ. Sci. 2021, 11, 178. [CrossRef]

28. Mura Paroche, M.; Caton, S.J.; Vereijken, C.M.J.L.; Weenen, H.; Houston-Price, C. How infants and young children learn about food: A systematic review. Front. Physiol. 2017, 8, 1046. [CrossRef]

29. Birch, L.L.; Anzman, S.L. Learning to Eat in an Obesogenic Environment: A Developmental Systems Perspective on Childhood Obesity. Child Dev. Perspect. 2010, 4, 138-143. [CrossRef]

30. Birch, L.L. Effects of Peer Models' Food Choices and Eating Behaviors on Preschoolers' Food Preferences. Child Dev. 1980, 51, 489-496. [CrossRef]

31. Gibson, E.L.; Kreichauf, S.; Wildgruber, A.; Vögele, C.; Summerbell, C.D.; Nixon, C.; Moore, H.; Douthwaite, W.; Manios, Y. A narrative review of psychological and educational strategies applied to young children's eating behaviours aimed at reducing obesity risk. Obes. Rev. 2012, 13 (Suppl. S1), 85-95. [CrossRef]

32. Batsell, R.W.; Brown, A.S.; Ansfield, M.E.; Paschall, G.Y. "You will eat all of that!": A retrospective analysis of forced consumption episodes. Appetite 2002, 38, 211-219. [CrossRef]

33. Ventura, A.K.; Worobey, J. Early influences on the development of food preferences. Curr. Biol. 2013, 23, R401-R408. [CrossRef]

34. Brouse, C.H.; Chow, T.H.F. Exploring pre-operational and concrete operational children's thinking on nutrition: A case study. Health Educ. J. 2009, 68, 219-231. [CrossRef]

35. Hart, K.H.; Bishop, J.A.; Truby, H. An investigation into school children's knowledge and awareness of food and nutrition. J. Hum. Nutr. Diet. 2002, 15, 129-140. [CrossRef]

36. Turner, S.A. Children's understanding of food and health in primary classrooms. Int. J. Sci. Educ. 1997, 19, 491-508. [CrossRef]

37. Stewart, K.; Gill, P.; Treasure, E.; Chadwick, B. Understandings about Food among 6-11 Year Olds in South Wales. Food Cult. Soc. 2006, 9, 317-336. [CrossRef]

38. Contento, I. Children's thinking about food and eating-A piagetian-based study. J. Nutr. Educ. 1981, 13, S86-S90. [CrossRef]

39. Zarnowiecki, D.; Sinn, N.; Petkov, J.; Dollman, J. Parental nutrition knowledge and attitudes as predictors of 5-6-year-old children's healthy food knowledge. Public Health Nutr. 2012, 15, 1284-1290. [CrossRef] [PubMed]

40. Herman, A.; Nelson, B.B.; Teutsch, C.; Chung, P.J. “Eat Healthy, Stay Active!": A coordinated intervention to improve nutrition and physical activity among Head Start parents, staff, and children. Am. J. Health Promot. 2012, 27, 27-36. [CrossRef] [PubMed]

41. Epstein, L.H.; Gordy, C.C.; Raynor, H.A.; Beddome, M.; Kilanowski, C.K.; Paluch, R. Increasing fruit and vegetable intake and decreasing fat and sugar intake in families at risk for Childhood Obesity. Obes. Res. 2001, 9, 171-178. [CrossRef] [PubMed]

42. Katz, D.L. School-Based Interventions for Health Promotion and Weight Control: Not Just Waiting on the World to Change. Annu. Rev. Public Health 2009, 30, 253-272. [CrossRef] [PubMed]

43. Stage, V.C.; Wilkerson, K.; Hegde, A.; Lisson, S.; Babatunde, O.T.; Goodell, L.S. Head Start administrator and teacher perceptions of parental influence on preschool children's nutrition education. J. Early Child. Res. 2018, 16, 160-175. [CrossRef]

44. Summerbell, C.; Waters, E.; Edmunds, L.; Kelly, S.; Brown, T.; Campbell, K. Interventions for preventing obesity in children (Review). Cochrane Database Syst. Rev. 2005, 3, 1-80. [CrossRef]

45. Bernal, R.; Attanasio, O.; Peña, X.; Vera-Hernández, M. The effects of the transition from home-based childcare to childcare centers on children's health and development in Colombia. Early Child. Res. Q. 2019, 47, 418-431. [CrossRef] 
46. Márquez, C.; Pedreira, M. Dialogar sobre lo esencial: Una propuesta de trabajo en la clase de ciencias. Alambique Didáctica De Las Cienc. Exp. 2005, 44, 105-112.

47. Olsen, N.J.; Buch-Andersen, T.; Handel, M.N.; Ostergaard, L.M.; Pedersen, J.; Seeger, C.; Stougaard, M.; Traerup, M.; Livemore, K.; Mortensen, E.L.; et al. The Healthy Start project: A randomized, controlled intervention to prevent overweight among normal weight, preschool children at high risk of future overweight. BMC Public Health 2012, 12, 1-12. [CrossRef]

48. Sharma, S.V.; Hedberg, A.M.; Skala, K.A.; Chuang, R.J.; Lewis, T. Feasibility and acceptability of a gardening-based nutrition education program in preschoolers from low-income, minority populations. J. Early Child. Res. 2015, 13, 93-110. [CrossRef]

49. Eugenio-Gozalbo, M.; Ramos Truchero, G.; Vallés Rapp, C. Huertos universitarios: Dimensiones de aprendizaje percibidas por los futuros maestros. Enseñanza De Las Cienc. 2019, 37, 111-127. [CrossRef]

50. Ceballos, M.; Escobar, T.; Vílchez, J.E. El huerto escolar: Percepción de futuros maestros sobre su utilidad didáctica. En Actas XXVI Encuentros De Didáctica De Las Cienc. Exp. 2014, 26, 285-292. Available online: https: / /bit.ly/37T4Usm (accessed on 2 June 2021).

51. Orenes Cárceles, J.; Ayuso, G.E.; Fernández Díaz, M.; Egea-Fernández, J.M. Huertos ecodidácticos: Percepciones sobre formación de profesorado y futuros docentes. Investig. En La Esc. 2021, 103, 1-18. [CrossRef]

52. Reina, M.; Vílchez, J.E.; Ceballos, M.; López, J.M. Análisis de un proyecto de huerto escolar en secundaria a partir de las percepciones de los estudiantes. Enseñanza De Las Cienc. Rev. De Investig. yY Exp. Didácticas. 2017, pp. 1491-1496. Available online: https://bit.ly/3kv58Lr (accessed on 23 July 2021).

53. Castaneda, M. El huerto escolar como herramienta pedagógica para la asignatura de Ciencia Salud y Medio Ambiente en el Tercer ciclo del Centro Escolar Instituto Nacional de Santa Ana. Conoc. Educ. 2019, 6, 69-85. [CrossRef]

54. Sántiz, G. El huerto Escolar, Oportunidad para Fortalecer el Trabajo Colaborativo y la Integración Entre los Estudiantes de Escuelas Primarias. Tesis de Maestría, El Colegio de la Frontera Sur, San Cristóbal de Las Casas, México, 2018. Available online: http:/ / bit.ly/3b1HrHB (accessed on 17 June 2021).

55. Marín-Gil, J. El huerto escolar: Mágica fuente de conocimiento y sabiduría. Aula 2015, 239, 44-47. Available online: http:/ /bit.ly/ 3bKaoqw (accessed on 16 July 2021).

56. López Martínez, J.D.; López Banet, L. Cotos escolares: Espacios educativos para la enseñanza de las ciencias en la escuela española del siglo XX. Bordón 2017, 69, 161-174. [CrossRef]

57. Eugenio-Gozalbo, M.; Aragón, L. Experiencias en torno al huerto ecológico como recurso didáctico y contexto de aprendizaje en la formación inicial de maestros de Infantil. Rev. Eureka Sobre Enseñanza Divulg. De Las Cienc. 2016, 13, 667-679. [CrossRef]

58. Zuazagoitia, D.; Aragón, L.; Ruiz, A.; Eugenio-Gozalbo, M.; Rodríguez, F. El desarrollo de la competencia científica del profesorado en formación inicial en el contexto de los huertos ecodidácticos: Diseño de una secuencia didáctica en torno al suelo y la ciencia ciudadana. Boletín ENCIC. Rev. Del Grupo De Investig. HUM-974 2019, 3, 138-141. Available online: https://bit.ly/3e8Tjrq (accessed on 16 July 2021).

59. Kambouri, M. Investigating early years teachers' understanding and response to children's preconceptions. Eur. Early Child. Educ. Res. J. 2016, 24, 907-927. [CrossRef]

60. Jorba, J.; Sanmartí, N. Un dispositivo pedagógico que incorpora la regulación continua de los aprendizajes. In Enseñar Aprender $Y$ Evaluar: Un Proceso De Evaluación Contin; Jorba, J., Sanmartí, N., Eds.; Ministerio de Educación y Cultura: Barcelona, Spain, 1994; pp. 33-94.

61. Pujol, R.M. Didáctica de las Ciencias en la Educación Primaria; Síntesis Educación: Madrid, Spain, 2003.

62. Tort, C.M.; Bargalló, M.R. Plantear preguntas: Un punto de partida para aprender ciencias. Rev. Educ. Y Pedagog. 2006, XVIII, 63-71.

63. Galindo, A.A.G.; Sanmartí, N.; Pujol, R.M. Fundamentación teórica y diseño de una unidad didáctica para la enseñanza del modelo ser vivo en la escuela primaria investigación didáctica. Enseñanza De Las Cienc. 2007, 25, 325-340.

64. Sanmartí, N. Evaluar para aprender. Aula De Infant. 2008, 44, 17-18.

65. Ravanis, K.; Koliopoulos, D.; Boilevin, J.-M. Construction of a precursor model for the concept of rolling friction in the thought of preschool age children: A socio-cognitive teaching intervention. Res. Sci. Educ. 2008, 38, 421-434. [CrossRef]

66. Ravanis, K.; Christidou, V.; Hatzinikita, V. Enhancing conceptual change in preschool children's representations of light: A socio-cognitive approach. Res. Sci. Educ. 2013, 43, 2257-2276. [CrossRef]

67. García Herránz, S.; López-Pastor, V.M. Evaluación Formativa y Compartida en Educación Infantil. Revisión de una Experiencia Didáctica. Qual. Res. Educ. 2015, 4, 269-298. [CrossRef]

68. Nicolás, C.; Menargues, A.; Limiñana, R.; Rey, A.; Rosa-Cintas, S.; Martínez-Torregrosa, J. Análisis y detección de las concepciones espontáneas sobre reproducción en plantas para la mejora de la enseñanza en Educación Primaria. Enseñanza De Las Cienc. 2017 1003-1008. Available online: https:/ / raco.cat/index.php/Ensenanza/article/view/335134 (accessed on 6 December 2021).

69. World Health Organization. Report of the Commission on Ending Childhood Obesity; WHO Library Cataloguing-in-Publication Data; WHO Document Production Services: Geneva, Switzerland, 2016; ISBN 978-92-4-151006-6.

70. British Nutrition Foundation. National Pupil Survey: UK Survey Results; BNF: London, UK, 2013.

71. Ponce-Blandón, J.A.; Pabón-Carrasco, M.; de las Mercedes Lomas-Campos, M. Análisis de contenido de la publicidad de productos alimenticios dirigidos a la población infantil. Gac. Sanit. 2017, 31, 180-186. [CrossRef] 